\title{
Morphology of Panicum genotypes submitted to periods of cessation of irrigation
}

\section{Morfologia de genótipos de Panicum submetidos à suspensão hídrica}

\author{
Amanda Ferreira de Limaํㅗ Mércia Virgínia Ferreira dos Santos#, Mário de Andrade Lira2\#, \\ Márcio Vieira da Cunhaㄹ, Alexandre Carneiro Leão de Mello#, Rinaldo Luiz Caraciolo Ferreira3\#, \\ André Pereira Freire Ferraz ${ }^{*}$, José Carlos Batista Dubeux Júnior ${ }^{4}$ and Janete Gomes de Moura ${ }^{1}$
}

\author{
${ }^{1}$ Animal Science Department, Universidade Federal Rural de Pernambuco (UFRPE). Zip code 52171-900, Dom Manoel de Medeiros street, Recife, Pernambuco, Brazil \\ 2 Instituto Agronômico de Pernambuco (IPA). Zip code 50761-000, General San Martin avenue, 1371, Recife, Pernambuco, Brazil \\ ${ }^{3}$ Department of Forest Sciences, UFRPE \\ ${ }^{4}$ University of Florida, North Florida Research \& Education Center, Marianna, Florida, United States of America \\ "CNPq research productivity scholarship \\ ( ${ }^{\star}$-mail:andrepfferraz@gmail.com) \\ http://dx.doi.org/10.19084/RCA18002
}

Received/recebido: 2018.01.03

Accepted/aceite: 2018.06.15

\begin{abstract}
A B S T R A C T
This study aimed to evaluate the morphological characteristics of Panicum maximum clones during the regrowth period following cessation of irrigation. Panicum clones were collected in Sergipe and in three Pernambuco locations ('São Bento do Una', 'Itambé' and 'São João da Coroa Grande'), in addition to 'Mombaça', 'Tanzânia' and 'Massai' cultivars. The treatments consisted of seven clones, which were subjected to either 7, 14, 21 or 28 days of water suspension. The experimental design was completely randomized in a factorial $7 \times 4$ design, with four replicates. The morphological characteristics evaluated included the number of tillers, plant height, leaf blade length, number of green leaves per tiller and number of dead leaves per tiller. The clone factor significantly affected the number of tillers per pot and the number of dead leaves per tiller $(\mathrm{P} \leq 0.05)$. The clone from Sergipe produced a greater number of tillers (8.39) than the other clones following 28 days of water suspension, while the 'Mombaça' cultivar had a greater number of dead leaves (5.39) after 7 days of water suspension. In general, the 28-day cessation of irrigation period resulted in taller plants with larger leaf blades and a greater number of green leaves per tiller.
\end{abstract}

Keywords: ecotype, forage grass, semiarid region, water stress

\section{R E S U M O}

Objetivou-se avaliar características morfológicas de clones de Panicum maximum durante o período de rebrota após a interrupção da irrigação. Os clones de Panicum foram coletados em Sergipe e em três locais de Pernambuco ("São Bento do Una", "Itambé" e "São João da Coroa Grande"), além das cultivares 'Mombaça', 'Tanzânia' e 'Massai'. Os tratamentos consistiram de sete clones submetidos a 7, 14, 21 ou 28 dias de suspensão da irrigação. O delineamento utilizado foi o inteiramente casualizado em arranjo fatorial $7 \times 4$ com quatro repetições. Foram avaliados o número de perfilhos, altura da planta, comprimento da lâmina foliar, número de folhas verdes por perfilho e número de folhas mortas por perfilho. O fator clone afetou significativamente o número de perfilhos por vaso e o número de folhas mortas por perfilho $(\mathrm{P} \leq 0,05)$. O clone de Sergipe produziu mais perfilhos (8.39) que os demais após 28 dias de interrupção da irrigação, enquanto a cultivar 'Mombaça' apresentou mais folhas mortas (5.39) após 7 dias sem irrigação. Em geral, a interrupção da irrigação por 28 dias resultou em plantas mais altas com lâminas foliares maiores e com número superior de folhas verdes por perfilho.

Palavras-chave: ecótipo, gramínea forrageira, região semiárida, estresse hídrico 


\section{INTRODUCTION}

Pancium maximum Jacq. is the most productive tropical forage propagated from seed, and is used worldwide due to its high productivity, forage quality and adaptability to different soil and climatic conditions (Jank et al., 2010). Brazil has a large germplasm bank, which has allowed for improvement of this species (Victor et al., 2015). Panicum maximum is a $C_{4}$ forage plant with high yield potential. It has a high photosynthetic response with increasing light intensity (Pedreira et al., 2015), which is common in plants native to the Brazilian semi-arid region, where evapotranspiration exceeds rainfall, especially during dry seasons.

Drought affects many countries worldwide, and is one of the major outcomes of climate change, thought to have intensified this century (IPCC, 2012). Water scarcity is an important factor that limits crop production, and therefore, there has been a continued search for plants that are adapted to drought conditions. In Pentecoste, a city located in the semi-arid region of Ceará, Cutrim Junior et al. (2011) reported high production of green forage mass by Panicum (cv. 'Tanzânia'). A study by Aimar et al. (2014) evaluated two cultivars of p. virgatum (cv. 'Kanlow', tolerant to water stress, and cv. 'Greenville', sensitive to water stress) that had been subjected to water suspension. They observed that the height of the 'Kanlow' cultivar showed no significant difference compared to the irrigated control, indicating superior performance. In contrast, the height of the 'Greenville' cultivar, more sensitive to water stress, was lower.

Tolerance to low rainfall is one of the key selection criteria for semi-arid environments (Njarui et al., 2015). Moreover, another important feature for the persistence of species in a pastoral ecosystem is a high regrowth capacity (Euclides et al., 2014). Cecato et al. (2000) found that the 'Centenário,' 'KK8,' 'Mombaça,' 'Tanzânia' and 'Tobiatã' cultivars had the highest total dry matter and leaf production, both in the drought periods and in years with high-rainfall.

Another important factor is related to the recovery of plants after a period of limited water availability, and the duration of the deficit is crucial for the resumption of plant growth. Under field conditions, plants naturally experience alternating wet and drought periods. Therefore, they need to be able to recover growth after prolonged periods of drought. In addition, the degree of recovery under different levels of water stress can vary between plants (Loewenstein and Pallardy, 2002; Xu et al., 2010), and the drought tolerance of grasses is closely related to its morphological characteristics (Bahrani et al., 2010).

The Agreste region and the semi-arid region of Pernambuco, are characterized by areas with irregular rainfall distribution. Within these areas, plants of the Panicum genus spontaneously occur, demonstrating their adaptation to these conditions. Thus, the objective of this study was to evaluate the morphological characteristics of p. maximum clones subjected to different periods of irrigation cessation.

\section{MATERIAL AND METHODS}

The experiment was carried out in a greenhouse at the Animal Science Department of the Universidade Federal Rural de Pernambuco (UFRPE) in Recife, Brazil. During the period in which the morphological evaluations were conducted (June to August 2008), the monthly temperature $\left({ }^{\circ} \mathrm{C}\right)$ and relative humidity (\%) was recorded using a digital thermo-hygrometer. Temperatures and relative humidity values of $28.2^{\circ} \mathrm{C}$ and $73 \%, 25.7^{\circ} \mathrm{C}$ and $84 \%$ and $28.4^{\circ} \mathrm{C}$ and $73 \%$ were recorded in June, July and August, respectively.

The plants were grown in translucent pots $(30 \mathrm{~cm}$ deep) with a capacity for $7.5 \mathrm{~kg}$ of substrate. Drains made from silicone hose $(0.25$ inches $\times 10 \mathrm{~cm})$ were attached to the underside (lateral) of each pot. Gravel was added to a height slightly above the drain, and $6 \mathrm{~kg}$ of soil was added to each pot. This soil (ultisol) (EMBRAPA, 2013) was collected from 0-20 cm depth, which was sieved and air dried prior to use. A chemical analysis was performed to characterize the soil: $\mathrm{pH}\left(\mathrm{H}_{2} \mathrm{O}\right)=5$; $\mathrm{P}($ Mehlich-1 $)=$ $5.0 \mathrm{mg} / \mathrm{dm}^{3} ; \mathrm{K}^{+}=0.17 \mathrm{cmolc} / \mathrm{dm}^{3} ; \mathrm{Na}^{+}=0.05 \mathrm{cmolc} / \mathrm{dm}^{3} ;$ $\mathrm{Ca}^{+2}+\mathrm{Mg}^{+2}=3.65 \mathrm{cmolc} / \mathrm{dm}^{3} ; \mathrm{Al}^{+3}=0.75 \mathrm{cmolc} / \mathrm{dm}^{3} ;$ cation exchange capacity $=15.8 \mathrm{cmolc} / \mathrm{dm}^{3}$; $\mathrm{S}=3.9 \mathrm{cmolc} / \mathrm{dm}^{3}$; and base saturation $=25 \%$. 
Soil liming was performed in February 2008, using the equivalent of $2 \mathrm{t} / \mathrm{ha}$ of dolomitic limestone $(0.0384 \mathrm{~kg} /$ pot). In March, the plants were established in the pots by transplanting seedlings, and in April of the same year, nitrogen fertilization (50 kg N/ha urea, equivalent to $0.00232 \mathrm{~kg} /$ pot) was carried out. The first standardization cutting was performed 5 days after the seedlings were transplanted, and the second standardization cutting and thinning occurred 37 days later, leaving three tillers per pot. At both points, cuts were made $20 \mathrm{~cm}$ from the surface of the substrate. The irrigation cessation period began 28 days after the second cutting. This period consisted of subjecting the plants to either 7, 14, 21 or 28 days without irrigation, depending on the treatment group. The plants were harvested (at $20 \mathrm{~cm}$ ) after each period, and evaluation of the morphological characteristics of the regrowth was performed. These morphological evaluations were performed on alternating days for a total of seven evaluations (14 days).

Seven clones of p.maximum were evaluated in this study, including three cultivars ('Tanzânia', 'Massai' and 'Mombaça') and four clones collected from the state of 'Sergipe' - Brazil, 'São Bento do Una,' 'São José da Coroa Grande' and 'Itambé', which had been grown in pots in a greenhouse (Table 1). The last three places are cities belonging to the state of 'Pernambuco,' Brazil. The cultivars were derived from plants belonging to the Collection of Forage Plants of the Animal Science Department at UFRPE.

Irrigation was carried out on alternate days (one day with and one day without irrigation) from when the seedlings were transplanted until the beginning of the irrigation cessation period, according to pot capacity. Irrigation was resumed during the regrowth period, when the morphological evaluations were performed, according to pot capacity (Casaroli and Van Lier, 2008).

Two tillers per pot were selected for the morphological evaluations and marked with colored ribbons, with the exception of the number of tillers, which was determined per pot. A graduated tape measure was used for the measurements of marked tillers. The response variables measured were: plant height (distance from the soil surface to the apex of the highest extended leaf); length of the leaf (leaf blade expanded in the marked tillers); number of green leaves (the number of green leaves that were growing or had completely expanded in the marked tillers); number of dead leaves; and total number of tillers per pot. The leaves were considered to be green in the absence of any signs of deterioration. The total number of tillers and the number of dead leaves per tiller were recorded at the end of each cessation of irrigation period, as well as during the regrowth period.

The treatments groups were determined by a completely randomized $7 \times 4$ factorial design (seven clones $\times$ four cessation of irrigation periods), with four replicates, totaling 112 plots. The qualitative factor (the clones) was subjected to analysis of variance (ANOVA), followed by a mean comparison test (Tukey's test; $\mathrm{P} \leq 0.05$ considered statistically significant) for the different water suspension periods. The quantitative factor (period of irrigation cessation) was analyzed by regression analysis ( $\mathrm{P} \leq 0.05)$. All statistical analyses were performed using GraphPad Prism software (version 5.1; GraphPad Software Inc., CA, USA).

Table 1 - Characteristics of the collection sites of Panicum materials

\begin{tabular}{lcccc}
\hline \multicolumn{1}{c}{ Sites/ } & S.J.C.G. & Itambé & S.B.U. & Sergipe* $^{*}$ \\
\cline { 2 - 5 } \multicolumn{1}{c}{ characteristics } & \multicolumn{3}{c}{ Pernambuco } & - \\
\hline Localization & South coast & 'Zona da mata' & Agreste & - \\
Climate & Tropical As' & Tropical As' & Semi-arid BSh & - \\
Altitude $(\mathrm{m})$ & 2 & 146 & 614 & - \\
Average air temperature & 23,7 & 24 & 26,2 & 22,7 a 26,5 \\
$\left({ }^{\circ} \mathrm{C}\right)$ & $1557,14^{(1)}$ & $1194,64^{(2)}$ & $666,78^{(3)}$ & $985^{(4)}$ \\
Annual rain $(\mathrm{mm})$ & & &
\end{tabular}

S.J.C.G. = São José da Coroa Grande; S.B.U. = São Bento do Una. (1) Historical data of 21 (1993-2015), (2)36 (1980-2015) and (3)35 years (1981-2015). Source: Agência Pernambucana de Águas e Clima (APAC).

*General characterization of the state of Sergipe. Source: Centro de Meteorologia de Sergipe (CEMESE); (4) Data from a series of 11 years (2003-2013). 


\section{RESULTS AND DISCUSSION}

The total number of tillers per pot differed between clones ( $\mathrm{P} \leq 0.05$; Table 2$)$. However, differences between the clones were only evident after 28 days of water suspension.

The clone from 'São Bento do Una' had the lowest number of tillers. This plant originates from an environment of low rainfall (Table 1), therefore, this result may be related to adaptations for limited water availability in the soil in order to increase their persistence in the pasture. Frank and Karn (1988) reported that genotypes with high growth rates are less tolerant to drought. It is noteworthy that the municipality of São Bento do Una has the highest intensity and frequency of droughts among the evaluated sites. Njarui et al. (2015) evaluated the persistence of 19 ecotypes of $p$. maximum in three locations with different rainfall (1010, 710 and 510 $\mathrm{mm}$ per year), and found that the number of tillers and dry mass per tiller were positively correlated with the amount of rainfall. Thus, programs that aim to determine clones that are more adapted to conditions of limited water availability should consider the number of tillers as a response variable.

Table 2 - Total number of tillers and dead leaves per tiller corresponding to the regrowth of $P$. maximum clones after cessation of irrigation periods

\begin{tabular}{|c|c|c|c|c|}
\hline \multirow{3}{*}{$\begin{array}{l}\text { Origin/ } \\
\text { Cultivars }\end{array}$} & \multicolumn{4}{|c|}{ Cessation of irrigation periods (days) } \\
\hline & 7 & 14 & 21 & 28 \\
\hline & \multicolumn{4}{|c|}{ Total number of tillers per pot } \\
\hline São Bento do Una & $3,96 \mathrm{a}$ & $3,61 \mathrm{a}$ & 3,68 a & $3,14 \mathrm{c}$ \\
\hline São José da Coroa Grande & $5,29 \mathrm{a}$ & $4,82 \mathrm{a}$ & 4,03 a & $5,04 \mathrm{abc}$ \\
\hline Itambé & $5,68 \mathrm{a}$ & $5,71 \mathrm{a}$ & $4,71 \mathrm{a}$ & $6,32 \mathrm{abc}$ \\
\hline Sergipe & $7,82 \mathrm{a}$ & $6,64 \mathrm{a}$ & $6,61 \mathrm{a}$ & 8,39 a \\
\hline Mombaça & $4,18 \mathrm{a}$ & $6,25 \mathrm{a}$ & $5,61 \mathrm{a}$ & $3,75 \mathrm{bc}$ \\
\hline Tanzânia & $5,86 \mathrm{a}$ & $4,86 \mathrm{a}$ & $5,64 \mathrm{a}$ & $4,93 \mathrm{abc}$ \\
\hline Massai & $5,82 \mathrm{a}$ & $5,89 \mathrm{a}$ & $4,93 \mathrm{a}$ & $5,75 \mathrm{abc}$ \\
\hline \multirow[t]{2}{*}{ Coefficient of variation (\%) } & 22,64 & 21,91 & 12,85 & 23,43 \\
\hline & \multicolumn{4}{|c|}{ Number of dead leaves per tiller } \\
\hline São Bento do Una & $4,86 \mathrm{ab}$ & $4,39 \mathrm{a}$ & $3,00 \mathrm{a}$ & 3,86 a \\
\hline São José da Coroa Grande & $2,82 \mathrm{bc}$ & $4,36 \mathrm{a}$ & $4,21 \mathrm{a}$ & $3,04 \mathrm{a}$ \\
\hline Itambé & $3,71 a b c$ & $3,68 \mathrm{a}$ & $4,04 \mathrm{a}$ & $4,18 \mathrm{a}$ \\
\hline Sergipe & $4,18 \mathrm{abc}$ & $3,96 \mathrm{a}$ & $4,50 \mathrm{a}$ & $4,21 \mathrm{a}$ \\
\hline Mombaça & $5,39 \mathrm{a}$ & $5,14 \mathrm{a}$ & $5,93 \mathrm{a}$ & $3,00 \mathrm{a}$ \\
\hline Tanzânia & $2,29 \mathrm{c}$ & $3,64 \mathrm{a}$ & $3,93 \mathrm{a}$ & $4,21 \mathrm{a}$ \\
\hline Massai & $4,57 \mathrm{abc}$ & $3,82 \mathrm{a}$ & $3,32 \mathrm{a}$ & 3,86 a \\
\hline Coefficient of variation (\%) & 25,60 & 23,36 & 22,67 & 20,98 \\
\hline
\end{tabular}

Averages followed by the same letter in the column do not differ from each other by the Tukey test at $5 \%$.
While there were differences observed between the clones for the number of tillers after 28 days of irrigation cessation (Table 2), the number of tillers was not affected during the periods of water suspension. On average, the clones from 'São Bento do Una,' 'São José da Cora Grande,' 'Itambé' and 'Sergipe' had 3.6 \pm 0.3, $4.8 \pm 0.5,5.6$ \pm 0.7 and $7.4 \pm 0.9$ tillers per pot, respectively, and the 'Mombaça,' 'Tanzânia' and 'Massai' cultivars had $4.9 \pm 1.2,5.3 \pm 0.5$ and $5.6 \pm 0.4$ tillers per pot, respectively. However, the number of tillers per pot tended to increase with longer regrowth time. This effect was significantly greater when plants were exposed to 14 days of water cessation, and reached a maximum after 12.82 regrowth days, with an average of 5.92 tillers per pot (Figure 1).

There were no significant differences in the number of tillers for any of the other periods of water cessation during the regrowth time. Santos et al. (2011) previously evaluated the behavior of Pennisetum sp. clones under controlled water restriction periods. They found that when subjected to 14 days without irrigation, the growth of basal tillers was little affected in the Cameroon clone, but the Australian and HV-241 clones presented more severe dehydration symptoms.

The height of the clones during the regrowth period were not influenced by the period of water suspension $(\mathrm{P}>0.05)$. In contrast, there was a significant effect of the number of regrowth days

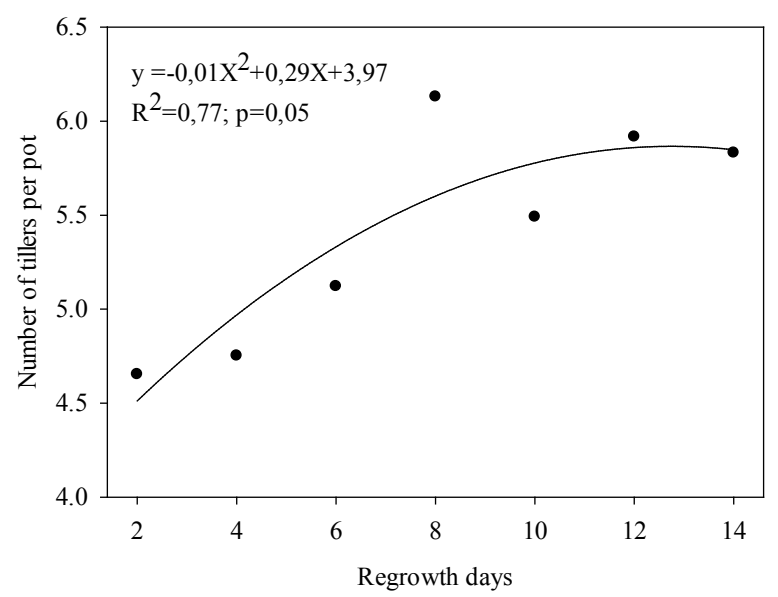

Figure 1 - Number of tillers per pot of $P$. maximum clones as a function of days of regrowth after 14 days of water suspension. 
(Figure 2A). After 2 days of regrowth, plants that had been subjected to 28 days of water suspension were taller (around $30 \mathrm{~cm}$ ), while plants exposed to the other periods had an average height of $25 \mathrm{~cm}$. The plants that were subjected to longer irrigation suspension periods were highest $(54.69 \mathrm{~cm})$ at the end of 14-day morphological evaluation.

$$
\begin{gathered}
\text { - } 7 \text { days water suspension } \\
---\quad \begin{array}{l}
\mathrm{y}=-0,14 \mathrm{X}^{2}+4,39 \mathrm{X}+14,29 \\
\mathrm{R}^{2}=0,98 ; \mathrm{p}=0,0002
\end{array}
\end{gathered}
$$

- 14 days water suspension

$$
\begin{gathered}
\mathrm{y}=-0,15 \mathrm{X}^{2}+5,09 \mathrm{X}+12,01 \\
\mathrm{R}^{2}=0,99 ; \mathrm{p}<0,0001
\end{gathered}
$$

v 21 days water suspension

$$
\begin{gathered}
\mathrm{y}=-0,20 \mathrm{X}^{2}+5,45 \mathrm{X}+13,29 \\
\mathrm{R}^{2}=0,99 ; \mathrm{p}<0,0001
\end{gathered}
$$

$\triangle \quad 28$ days water suspension

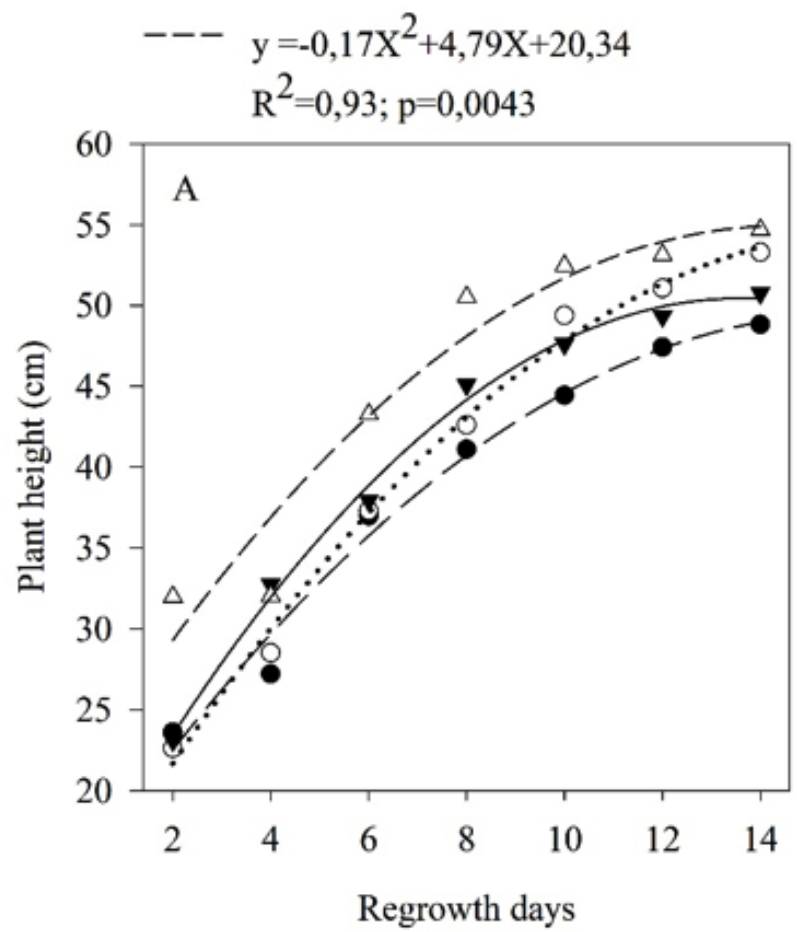

Similar behavior was observed for the length of the leaf blade. There were no significant effects between clones $(\mathrm{P}>0.05)$, however, significant differences were observed for the number of regrowth days (Figure 2B).

> 21 days water suspension

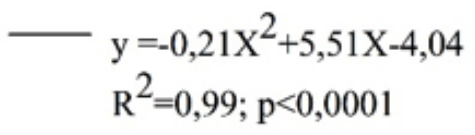

$\triangle \quad 28$ days water suspension

$---\quad y=-0,15 X^{2}+4,18 X+7,23$

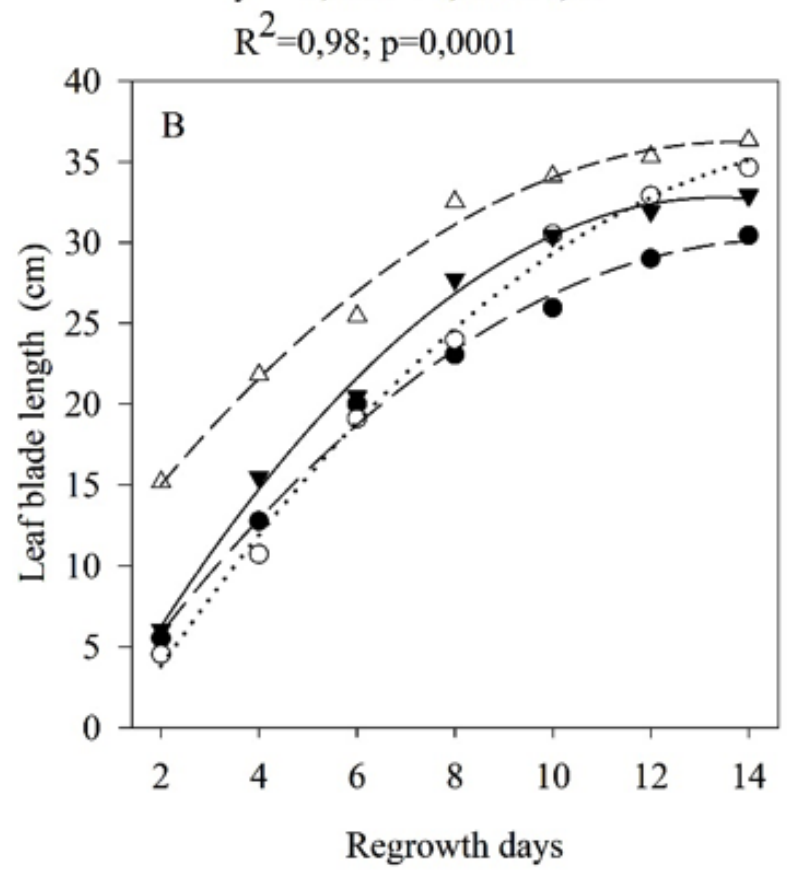

Figure 2 - Plant height (A) and leaf blade length (B) of P. maximum clones as a function of days of regrowth after water suspension periods. 
The length of the leaf blades ranged from 4 to $6 \mathrm{~cm}$ after two days of regrowth in plants subjected to between 7 and 21 days of irrigation cessation. The plants that had been subjected to 28 days of water suspension showed higher rates of leaf growth after 2 days of regrowth (mean of $6.09 \mathrm{~cm} \mathrm{day}^{-1}$ ) compared to the other treatments, with larger leaf blades $(36.32 \mathrm{~cm})$ observed at the 14-day evaluation. In contrast, Barreto et al. (2001) evaluated the morphological variables of Pennisetum clones and a pearl millet hybrid, observing a reduction in the leaf blade length from $69.9 \mathrm{~cm}$ in the irrigated plants to $50.0 \mathrm{~cm}$ in plants under water stress. Some authors have suggested that drought conditions may cause inhibition of cell wall synthesis and cell expansion (Farooq et al., 2009; Taiz and Zeiger, 2013), and consequently, reduced leaf growth (Van Volkenburgh, 1999), which contradicts the results observed in this study. However, Ludlow and $\mathrm{Ng}$ (1977) evaluated the leaf elongation rate in the $p$. maximum Trichoglume variety, and found that the magnitude at which drought affects the growth, through a reduction in leaf area, depends on the relationship between the expansion rate and the leaf water potential during the period of water stress. Therefore, Ludlow and Ng (1977) suggested that the stimulus for leaf expansion during stress is because cell division is less sensitive to water deficit than cell expansion.

There was no effect of the clone type on the number of green leaves per tiller for any of the cessation of irrigation periods, however, this variable was influenced by the number of regrowth days $(\mathrm{P} \leq 0.05)$ (Figure 3A). Plants that were subjected to 7-21 days of cessation of irrigation produced 1-2 leaves after two days of regrowth. In contrast, plants subjected to 28 days of water suspension produced almost three (2.84) green leaves per tiller on average during the first 2 days of regrowth, and an average of 4.37 green leaves per tiller after 14 days of regrowth (Figure 3A). This result is similar to that reported by Gomide et al. (2003), in which 5.3 green leaves per tiller were observed in 'Mombaça' grass (P. maximum) after 16 days of regrowth. It should be noted that, due to the longer cessation of irrigation period ( 28 days), the plants were cut after a longer growth period. Although the shoot was standardized in terms of height, these observations may result from further development of the root system and accumulation of organic reserves, with potential reallocation of resources during the regrowth phase.

In Brachiaria species (B. decumbens, B. brizantha, B. humidicola and B. mutica), Mattos et al. (2005) found that the $B$. brizantha species showed greater tolerance to drought as a result of several factors, including the significant production of roots. In another study, Doss et al. (1960) analyzed three water regimes (70, 35 and $15 \%$ soil moisture) in five warm-season forage plants (Paspalum dilatatum, p. notatum, Lespedeza cuneala, and coastal and common varieties of (ynodon dactylon), and found that the depth of the roots decreased with increasing water availability. Therefore, the root density increased with decreasing water availability.

For the number of dead leaves per tiller, we only observed an effect of the clone factor in plants that had been subjected to 7 days of water suspension (Table 2). In the 'Mombaça' cultivar, the highest number of green leaves grew above $20 \mathrm{~cm}$, which were removed during the uniformization process. Thus, the cutting process may have left less residual leaf area index, thereby hindering the restoration of plants, and consequently, increasing the number of dead leaves observed (5.89 dead leaves per tiller). There was also an effect of the number of regrowth days (Figure 3B), however, the correlation was low (average of $46.25 \%$ ) for all periods of water suspension, as shown by the $\mathrm{R}^{2}$ value (determination coefficient), in addition to the divergent results between the different cessation of irrigation periods. After 7 and 21 days of water suspension, there was a tendency toward a reduced number of dead leaves, however, this tended to increase in plants subjected to 14 and 28 days of water suspension. According to Lemaire and Chapman (1996), during the early stages of regrowth there is little or no dead leaf material, and this number increases with longer regrowth periods. 
- 7 days water suspension

$$
\begin{gathered}
---\quad \begin{array}{c}
y=-0,01 X^{2}+0,29 X+0,14 \\
R^{2}=0,91 ; p=0,0068
\end{array}
\end{gathered}
$$

○ 14 days water suspension

$$
y=-0,01 X^{2}+0,30 X+0,13
$$$$
\mathrm{R}^{2}=0,97 ; \mathrm{p}=0,0012
$$

v 21 days water suspension

$$
\begin{aligned}
& \mathrm{y}=0,19 \mathrm{X}+1,04 \\
& \mathrm{R}^{2}=0,90 ; \mathrm{p}=0,0011
\end{aligned}
$$

$\triangle \quad 28$ days water suspension

$$
---\quad \mathrm{y}=0,12 \mathrm{X}+2,67
$$

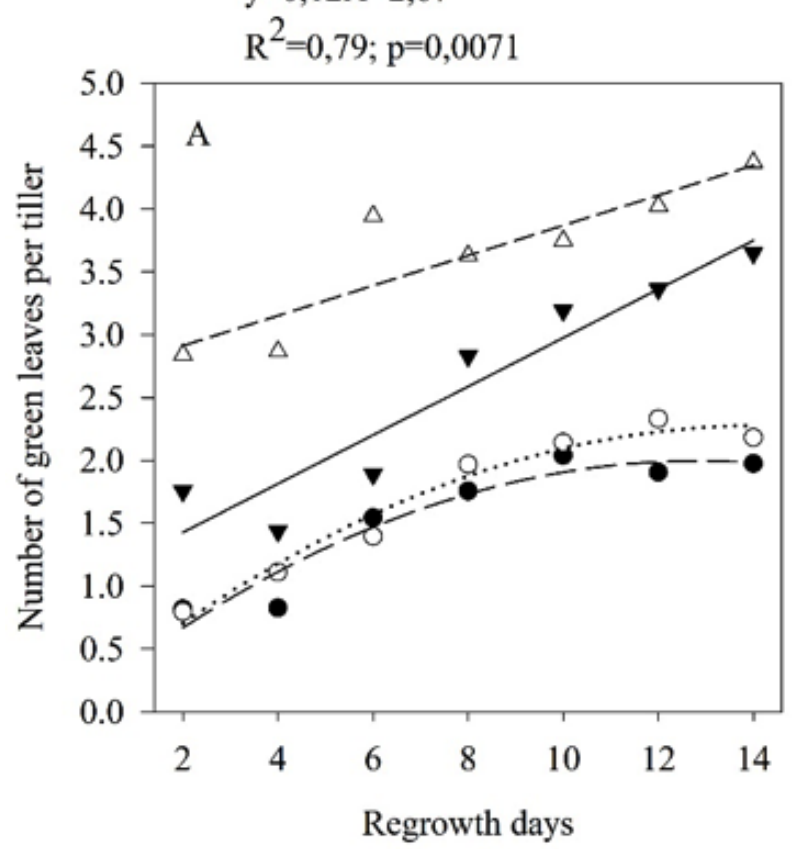

- 7 days water suspension

$$
\begin{aligned}
& \text { - - } \mathrm{y}=-0,02 \mathrm{X}^{2}+0,25 \mathrm{X}+3,07 \\
& \mathrm{R}^{2}=0,21 ; \mathrm{p}=0,6178
\end{aligned}
$$

○ 14 days water suspension

$$
y=0,04 X^{2}-0,63 X+6,25
$$$$
\mathrm{R}^{2}=0,78 ; \mathrm{p}=0,05
$$

v 21 days water suspension

$$
\begin{gathered}
\mathrm{y}=-0,02 \mathrm{X}^{2}+0,41 \mathrm{X}+2,89 \\
\mathrm{R}^{2}=0,41 ; \mathrm{p}=0,3470
\end{gathered}
$$

$\triangle \quad 28$ days water suspension

$$
---\quad y=0,02 X^{2}-0,24 X+4,38
$$

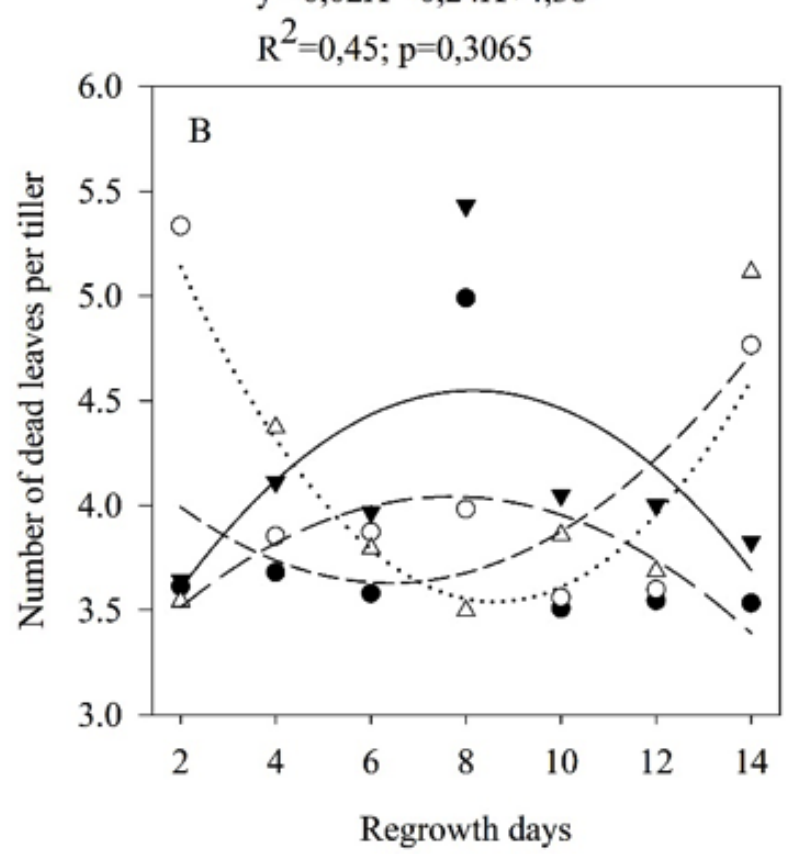

Figure 3 - Number of green leaves (A) and dead leaves per tiller (B) in P. maximum clones as a function of regrowth days after water suspension periods.

\section{CONCLUSION}

In conclusion, 28 days without irrigation resulted in Panicum clones that were taller, had larger leaf blades and an increased number of green leaves per tiller. These results suggest that cessation of irrigation for up to 28 days does not compromise plant growth. We emphasize that this research was conducted in greenhouse conditions, and that the evaluation of ecotypes under field conditions will provide greater understanding of the adaptation of these materials to different soil and climate conditions.

\section{ACKNOWLEDGEMENTS}

'Conselho Nacional de Desenvolvimento Científico e Tecnológico' (CNPq), 'Fundação de Amparo à Ciência e Tecnologia de Pernambuco' (FACEPE) and to 'Coordenação de Aperfeiçoamento de Pessoal de Nível Superior' (CAPES) are acknowledged. 


\section{REFERENCES}

Aimar, D.; Calafat, M.; Andrade, A.M.; Carassay, L.; Bouteau, F.; Abdala, G. \& Molas, M.L. (2014) - Drought effects on the early development stages of Panicum virgatum L.: Cultivar differences. Biomass and Bioenergy, vol. 66, p. 49-59. http://dx.doi.org/10.1016/j.biombioe.2014.03.004

Bahrani, M.J.; Bahrami, H. \& Haghighi, A.A.K. (2010) - Effect of water stress on ten forage grasses native or introduced to Iran. Grassland Science, vol. 56, n. 1, p. 1-5. http://dx.doi.org/10.1111/j.1744-697X.2009.00165.x

Barreto, G.P.; Lira, M.A.; Santos, M.V.F. \& Dubeux Jr, J.C.B. (2001) - Avaliação de clones de capim-elefante (Pennisetum purpureum Schum.) e de um híbrido com o milheto (Pennisetum glaucum (L.) R. Br.) submetidos a estresse hídrico. 1. Parâmetros morfológicos. Revista Brasileira de Zootecnia, vol. 30, n. 1, p. 1-6. http:// dx.doi.org/10.1590/S1516-35982001000100001

Casaroli, D. \& van Lier, Q. de J. (2008) - Critérios para determinação da capacidade de vaso. Revista Brasileira de Ciência do Solo, vol. 32, n. 1, p. 59-66. http://dx.doi.org/10.1590/50100-06832008000100007

Cecato, U.; Machado, A.O.; Martins, E.N.; Pereira, L.A.F.; Barbosa, M.A.A.F. \& Santos, G.T. (2000) - Avaliação da produção e de algumas características da rebrota de cultivares e acessos de Panicum maximum Jacq. sob duas alturas de corte. Revista Brasileira de Zootecnia, vol. 29, n. 3, p. 660-668. http://dx.doi.org/10.1590/S151635982000000300004

Cutrim Junior, J.A.A.; Cândido, M.J.D.; Valente, B.S.M.; Carneiro, M.S.S. \& Carneiro, H.A.V. (2011) Características estruturais do dossel de capim-tanzânia submetido a três frequências de desfolhação e dois resíduos pós-pastejo. Revista Brasileira de Zootecnia, vol. 40, n. 3, p. 489-497. http://dx.doi.org/10.1590/S151635982011000300005

Doss, B.D.; Ashley, D.A. \& Bennett, O.L. (1960) - Effect of soil moisture regime on root distribution of warm season forage species. Agronomy Journal, vol.52, n. 10, p. 569-572. http://dx.doi.org/10.2134/ agronj1960.00021962005200100005x

EMBRAPA (2013) - Sistema Brasileiro de Classificação de Solos. 3.ed. rev. ampl. - Brasília, DF: Embrapa. 353 p.

Euclides, V.P.B.; Montagner, D.B.; Barbosa, R.A. \& Nantes, N.N. (2014) - Manejo do pastejo de cultivares de Brachiaria brizantha (Hochst) Stapf e de Panicum maximum Jacq. Revista Ceres, vol. 61, p. 808-818. http:// dx.doi.org/10.1590/0034-737x201461000006

Farooq, M.; Wahid, A.; Kobayashiw. N.; Fujita, D. \& Basra, S.M.A. (2009) - Plant drought stress: effects, mechanisms and management. Agronomy for Sustainable Development, vol. 29, n. 1, p.185-212. http://dx.doi. org/10.1051/agro:2008021

Frank, A.B. \& Karn, J.F. (1988) - Growth, water-use efficiency, and digestibility of crested, intermediate, and western wheatgrass. Agronomy Journal, vol.80, n. 4, p.677-680. http://dx.doi.org/10.2134/ agronj1988.00021962008000040024x

Gomide, C.M.A.; Gomide, J.A. \& Alexandrino, E. (2003) - Índices morfogênicos e de crescimento durante o estabelecimento e a rebrotação do capim-Mombaça (Panicum maximum Jacq.). Revista Brasileira de Zootecnia, vol. 32, n. 4, p. 795-803. http://dx.doi.org/10.1590/S1516-35982003000400003

IPCC (2012) - Managing the risks of extreme events and disasters to advance climate change adaptation. A Special Report of Working Groups I and II of the Intergovernmental Panel on Climate Change. Cambridge University Press, Cambridge, UK, and New York, NY, USA.

Jank, L.; Martuscello, J.A.; Euclides, V.P.B.; Valle, C.B. \& Resende, R.M.S. (2010) - Panicum maximum. In: Fonseca, D.M. \& Martuscello, J.A. (Eds.) - Plantas forrageiras. - Viçosa, MG: Ed. UFV. p. 166-196.

Lemaire, G. \& Chapman, D. (1996) - Tissue flows in grazed plant communities. In: Hodgson, J. \& Illius, A.W. (Eds.) - The ecology and management of grazing systems. Wallingford: CAB International, 3-36.

Loewenstein, N.J. \& Pallardy, S.G. (2002) - Influence of a drying cycle on post-drought xylem sap abscisic acid and stomatal responses in young temperate deciduous angiosperms. New Phytologist, vol. 156, n. 3, p. 351-361. http://dx.doi.org/10.1046/j.1469-8137.2002.00528.x

Ludlow, M.M. \& Ng, T.T. (1977) - Leaf elongation rate in Panicum maximum var. trichoglume following removal of water stress. Australian Journal of Plant Physiology, vol. 4, n. 2, 263-272. http://dx.doi.org/10.1071/ PP9770263 
Mattos, J.L.S.; Gomide, J.A. \& Huaman, C.A.M. (2005) - Crescimento de espécies do gênero Brachiaria, sob déficit hídrico, em casa de vegetação. Revista Brasileira de Zootecnia, vol. 34, n. 3, p. 746-754. http://dx.doi. org/10.1590/S1516-35982005000300005

Njarui, D.M.G.; Gatheru, M.; Mwangi, D.M. \& Keya, G.A. (2015) - Persistence and productivity of selected Guinea grass ecotypes in semiarid tropical Kenya. Grassland Science, vol. 61, n. 3, p. 142-152. http://dx.doi. org/10.1111/grs.12092

Pedreira, B.C.; Pedreira, C.G.S. \& Lara, M.A.S. (2015) - Leaf age, leaf blade portion and light intensity as determinants of leaf photosynthesis in Panicum maximum Jacq. Grassland Science, vol. 61, n. 1, p. 45-49. https://doi.org/10.1111/grs.12080

Santos, M.C.S.; Lira, M.A.; Tabosa, J.N.; Mello, A.C.L. de \& Santos, M.V.F. (2011) - Comportamento de clones de Pennisetum submetidos a períodos de restrição hídrica controlada. Archivos de Zootecnia, vol. 60, n. 229, p. 31-39. http://dx.doi.org/10.4321/S0004-05922011000100004

Taiz, L. \& Zeiger, E. (2013) - Fisiologia vegetal. - 5.ed. Porto Alegre: Artmed. 918 p.

van Volkenburgh, E. (1999) - Leaf expansion - an integrating plant behavior. Plant, Cell and Environment, vol. 22, n. 12, p. 1463-1473. http://dx.doi.org/10.1046/j.1365-3040.1999.00514.x

Victor, D.M.; Jank, L.; Lempp, B.; Simeão, R.M.; Resende, M.D.V. \& Gonçalves, M.C. (2015) - Selection of fullsib families of Panicum maximum Jacq under low light conditions. Revista Ceres, vol. 62, n. 2, p. 199-207. http://dx.doi.org/10.1590/0034-737X201562020010

Xu, Z.; Zhou, G. \& Shimizu, H. (2010) - Plant responses to drought and rewatering. Plant Signaling E Behavior, vol. 5, n. 6, p. 649-654. https://doi.org/10.4161/psb.5.6.11398 